\title{
The Role of Attic Ventilation to Reduce Indoor Air Temperature in Zinc-Roofed Buildings in a Humid Tropical Climate
}

\author{
Jefrey I. Kindangen \\ Dept. of Architectural Engineering \\ Sam Ratulangi University
}

\author{
Manado, Indonesia \\ http://orcid.org/0000-0003-0126-5193 \\ Octavianus H.A. Rogi \\ Dept. of Architectural Engineering
}

\author{
Sam Ratulangi University \\ Manado, Indonesia \\ ottyrogi@gmail.com
}

\begin{abstract}
Many buildings were built using zinc roofs in North Sulawesi province, Indonesia, there is more than 92 percent of buildings with zinc roofs. Buildings in humid tropical climates often face the problem of excessive heat due to the solar radiation accumulates, especially on roofs that can propagate into occupied spaces. The use of zinc roofs can also cause excessive heat in the occupancy space if the construction does not consider the thermal properties of the material. This article aims to assess the benefits of attic ventilation, especially in buildings with zinc roofs to cut the indoor air temperature. This research has been carried out by building two similar test cells in which one cell has roof ventilation of $20 \%$ Net Free Ventilation Area and the other cell with an airtight attic. The measurement results showed that the use of attic ventilation causes the indoor air temperature to always be lower, on average $1.2{ }^{\circ} \mathrm{C}$. The same thing, by comparing the use of roof insulation; its use can cut the air temperature in the attic by 0.3 ${ }^{\circ} \mathrm{C}$. Comparisons show that at certain hours the indoor air temperature under an insulated roof is lower than under a ventilated roof. In contrast, the overall indoor air temperature is $0.1^{\circ} \mathrm{C}$ lower on the ventilated roof. This condition is rather difficult to conclude that the use of roof insulation is better than the use of roof ventilation. Further research is still needed to examine the effect of the attic vent area on reducing the indoor air temperature compared to the use of roof insulation.
\end{abstract}

Keywords: attic ventilation, insulated roof, zinc roof, indoor air temperature, Net Free Ventilation Area, hot humid climate

\section{INTRODUCTION}

Indonesia's climate conditions are humid tropical climates which have always been the main problem causing thermal discomfort. In a hot environment coupled with high air humidity, a person will feel hot and will sweat. A person will feel uncomfortable if there is no evaporation from moist skin. In these conditions, it takes the flow of air to evaporate the sweat on the skin and psychologically and physiologically give the impression of thermal coolness. But the important thing to achieve thermal comfort is how to reduce the indoor air temperature. Thus reducing the indoor air temperature in the right way and energy-saving strategies are the best way to achieve the thermal comfort of occupants.

For this purpose, finding out the effect of roof ventilation to reduce the temperature of indoor air under the attic is very necessary. Besides, this is an effort to improve environmental quality and to implement energy-efficient building construction, which in turn reduces energy consumption from fossils that will contribute to the drastic prevention of climate change.

Several researchers have researched roof ventilation such as Beal et al. [1] has been done by comparing two types of roofing material: the ventilated tile roof compared to the black shingle roof; they obtained a $48 \%$ heat flux reduction for a ventilated tile roof. This seems to be due to the thermal mass of tile roofs and ventilation between tiles which is a dominant phenomenon in reducing the cooling load on the roof like this.

The use of roof ventilation is also suggested by Rose [2] who emphasizes the importance of research as above and recommends the use of ventilation to control the humidity in the space between the roof and the ceiling.

The US Department of Housing and Urban Development [3] which has reviewed and did literature studies to investigate roof ventilation design strategies for manufactured houses, has recommended the benefits of roof ventilation to control humidity, save energy, increase the durability of asphalt roofs, and avoid freezing ice. The research team recommended designing roof ventilation systems that differed according to climatic conditions in each of the US states that were very different from each other. This study showed that houses in hot and humid climates benefit more from the design of attic ventilation than houses without it. However, this research cannot necessarily be implemented in climatic conditions in Indonesia or humid tropical climates; and also for zinc roofing materials commonly used in the region. Corrugated zinc sheets as roof cover materials are widely used in Indonesia and especially in North Sulawesi Province according to data provided by the North Sulawesi's Central Agency of Statistics in 2016 [4], as follows:

TABLE I. TYPES OF ROOF MATERIALS IN NORTH SULAWESI PROVINCE, INDONESIA

\begin{tabular}{|c|c|}
\hline Types of roofing & Percentage of houses (\%) \\
\hline Galvanized zinc roof & 92.41 \\
\hline Shingle roof & 2.21 \\
\hline The roof of palm fiber & 2.10 \\
\hline Concrete roof & 1.85 \\
\hline Clay Tile roof & 1.00 \\
\hline Asbestos roof & 0.41 \\
\hline Others & 0.02 \\
\hline
\end{tabular}


This paper explains explicitly to know the effect of roof ventilation on zinc roof buildings that are often found in North Sulawesi. In connection with the compatibility between climate and architecture, Givoni [5] and Lippsmeier [6] have stated that there is a very close relationship between humans and climate that will affect the architecture in its place; even Olygay [7] stated that climate determines the architectural characteristics that exist in the climate region; including the use of materials that are common in the area. Efforts to create thermally comfortable spaces in buildings in humid tropics can be done with several passive cooling strategies, especially strategies that save energy as explained by Kindangen [8]. The use of attic ventilation is also one way to get thermal comfort in buildings in humid tropical climates such as can be found in almost all traditional houses in Indonesia and also in Dutch colonial heritage buildings in Indonesia [9, 10]. While about zinc roofing materials that are often used in this region, several attempts to cool zinc roofing have been carried out using evaporative cooling techniques and spraying water onto the roof surface, but these techniques require an impractical installation $[11,12,13]$.

In certain cases where construction and room layout do not allow natural roof ventilation to be used, it is recommended to use a turbine ventilator on the roof, as suggested by Ismail, M. et al. [14]. The use of roof turbine ventilators has been used in almost all types of buildings and is used because of climatic conditions that do not allow using natural roof ventilation. However, this use requires energy costs and can only be used in urgent conditions. A guideline for making ventilation more airtight with insulation has been issued by the U.S. Department of Energy's Building America, Program Office of Energy Efficiency and Renewable Energy [15]. But this cannot be applied in a humid tropical climate and is more suitable in a subtropical climate.

Roof ventilation design is needed for air humidity control and also to control indoor heat as suggested by Quarles et al. [16]. The same thing was done by Purswell et al. [17], they researched livestock pens and concluded that with roof ventilation humidity could be reduced compared to a house that has a traditional ventilation system on one side of the wall.

Research to investigate the effectiveness of the attic ventilation system to achieve heat comfort in the humid tropical climate has been carried out by Ahmed S. et al. [18]. This system consists of a solar-powered fan for attic ventilation, in other words, almost similar to previous researchers who used a ventilator. As a result, the temperature in a residential room can be reduced. Hot air trapped during the day is the main source of heat, this system has the potential to be used in humid tropical climates. The researches described above emphasize the use of turbine ventilators and has not investigated the roof ventilation system naturally. Therefore, this paper describes and investigates the effects of natural roof ventilation for houses in humid tropical climates.

\section{METHODS}

Two models of test houses have been established where one model does not have roof ventilation and the other model has roof ventilation. Ventilated roof models have ventilation holes placed on both sides of the roof. The total area of the roof ventilation holes on both sides is $20 \%$ of the ceiling or floor area. For both models, occupational space has two windows, each of which is located on both sides of the opposite wall. This is intended to get effective airflow in the room.

The same two test cells have been built which have a length of $1.00 \mathrm{~m}$, a width of $1.00 \mathrm{~m}$ and a height of $1.85 \mathrm{~m}$. The roof is made of corrugated zinc 0.2 with an unpainted surface area of $2.60 \mathrm{~m}^{2}$ and is tilted only in one direction. The wall is made of $2 \mathrm{~mm}$ plywood painted white and has two windows on the side facing each other, measuring $25 \times 50 \mathrm{~cm}$ with a total opening area equal to $25 \%$ of the floor area. It has a $70 \mathrm{~cm}$ window sill from the ground. These windows are located on the right and left side (North and South) to avoid direct sunlight that can penetrate through windows. The cells are placed outdoors in the field so that they can be exposed to direct sunlight as effectively as possible in the early morning hours. Dataloggers RC4-HC is used to measure air temperature and relative humidity, where for each test cell uses 2 dataloggers RC4-HC with proper placement, as illustrated in Figure. 1.

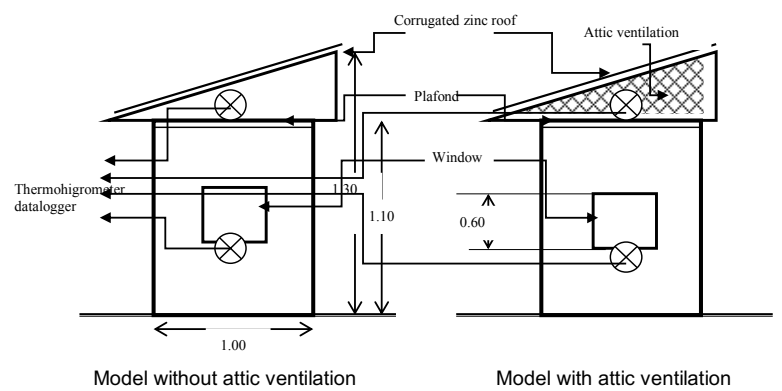

Fig. 1. Schematic design of two test models

The apparatus is used to measure and record the temperature and humidity of the air in the attic room, the space between the roof and the ceiling, and the indoor.

In principle, the test consists of 2 main parts. In the first test, we compared a building model that has a ventilated roof with a model that does not have it. Roof ventilation in the first model has a Net Free Ventilation Area (NFVA) of $20 \%$ of the floor area or attic area to be ventilated. Openings in a roof ventilated model are equipped with wire mesh. While in the second test we compared the roof-ventilated model with another model using roof insulation installed. The insulation used is a type of woven metalized foil, with one side of metalized foil bound to a reinforced high-density polyethylene woven fabric having a thickness of $0.003 \mathrm{~mm}$ and an emission index of $55+5 \%$ [19], as shown in Fig. 2. This insulation is placed just underneath the zinc roof on a building model without roof ventilation.
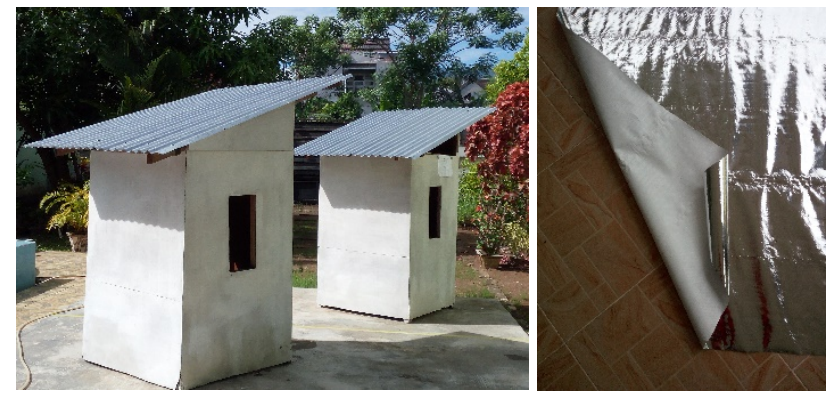

Fig. 2. Installation of two test models and the roof's insulation used 
On the first test, the two windows were left open; while in the second test the window on the North side was closed with transparent glass sheets and another window on the Southside remained open. This will also confirm the evidence of the influence of other parameters that will affect the climatic conditions of the room and its occupants.

Measurements were carried out at the end of November and the beginning of July for 10 consecutive days for each month. The climate conditions in Manado during these months are in the rainy and hot seasons. The rainy season usually occurs from November to March, while summer from April to October. The hottest months occur in October and the coldest month in January. The temperature difference between the hottest and coldest months is not too much different. For this reason, the measurement time is acceptable for testing.

The measurement results were downloaded from the data logger that had recorded the air temperature and relative humidity of the place specified, the data were then analyzed using the appropriate statistical method to obtain evidence of the importance of the role of roof ventilation.

\section{RESULTS AND DISCUSSION}

The use of roof ventilation provides benefits where the indoor air temperature is always lower than the temperature in cells without roof ventilation as indicated by the measurement results for 10 consecutive days, as shown in Fig. 3.

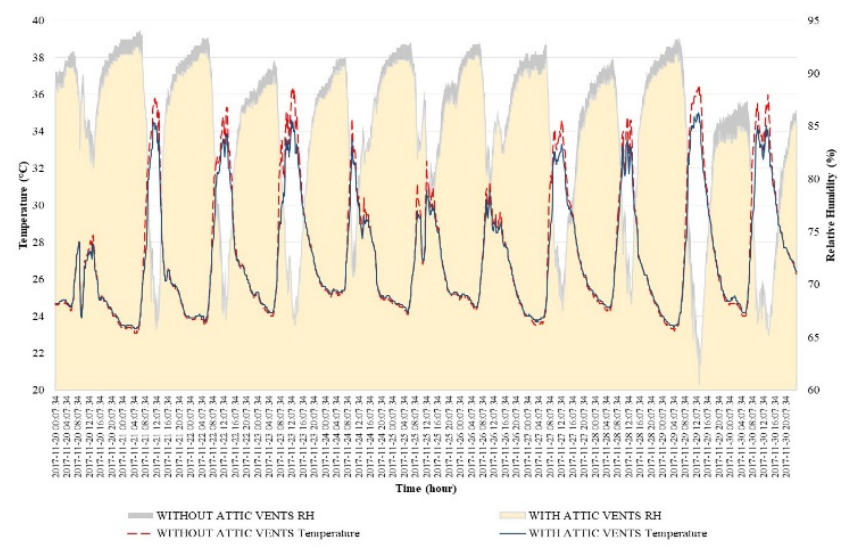

Fig. 3. Comparison of the indoor air temperature and air relative humidity from the ventilated roofs model and not

The indoor air temperature under a ventilated roof is always lower than the indoor air temperature of the unventilated roof, the difference was from 0.1 to $2.1{ }^{\circ} \mathrm{C}$ or an average of $1.2{ }^{\circ} \mathrm{C}$, especially during the day. At night the indoor air temperature of the two cells is the same or not significantly different. This is due to the cooling occurs at night where zinc is easily cooling down and does not require other strategies. The heat effect of metals during the day is more sensitive and effective and can cause significant warming during the day. It can be concluded that passive daytime cooling strategies such as cross ventilation and attic ventilation can provide significant benefits. The relative humidity of the indoor air from time to time fluctuates and follows proportionally with changes in air temperature, as illustrated in Fig.3.

In detail, on a single day, the indoor air temperature curve in the two cells is shown in Fig. 4 where from 7 a.m. to 4 p.m., the use of roof vents shows great benefit in lowering the indoor air temperature.

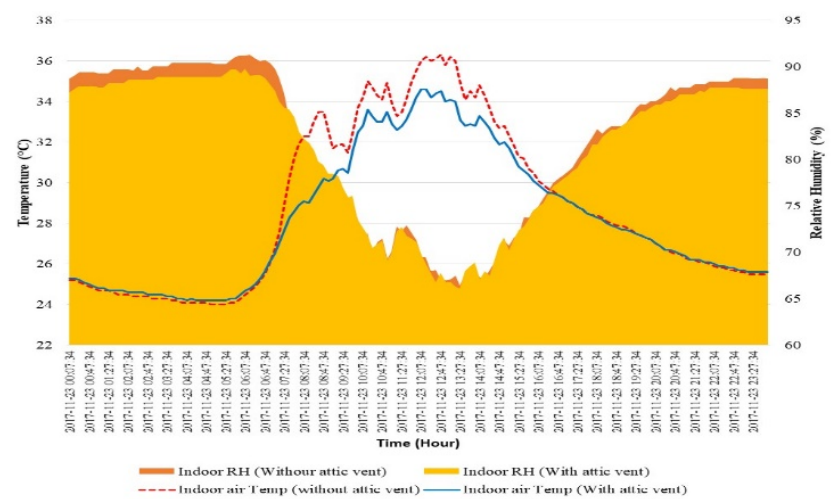

Fig. 4. Differences in detail in indoor air temperature from models that have roof ventilation and not

The difference between the two is not constant but changes, and can be assumed that caused by the influence of other parameters such as the velocity of airflow and the condition of air entering through the window. The speed of the wind entering the room is very dependent on its previous speed where the magnitude naturally changes; as well as the direction of coming. This can cause the difference to be not constant. This condition causes convective air cooling in the room to fluctuate constantly.

To investigate more deeply the effect of roof ventilation on decreasing indoor air temperature, we compared a model that has roof ventilation with a non-ventilated roof model but has insulation underneath the roof. The insulation used is woven metalized foil type with one side of metalized foil bound to reinforced high-density polyethylene with a thickness of $0.003 \mathrm{~mm}$. We also changed the installation of windows on the model by closing one of the windows located on the North side with transparent glass. This means that the room only has a single vent. This change is done on both models simultaneously.

Comparison of measurement results between the models shows a quite different pattern as the previous comparison, where the indoor air temperature of the roof-ventilated model is sometimes lower and sometimes higher than the indoor air temperature of the non ventilated but insulated roof, but the indoor air temperature difference between the two decreases compared to the first experiment, as shown in Fig. 5.

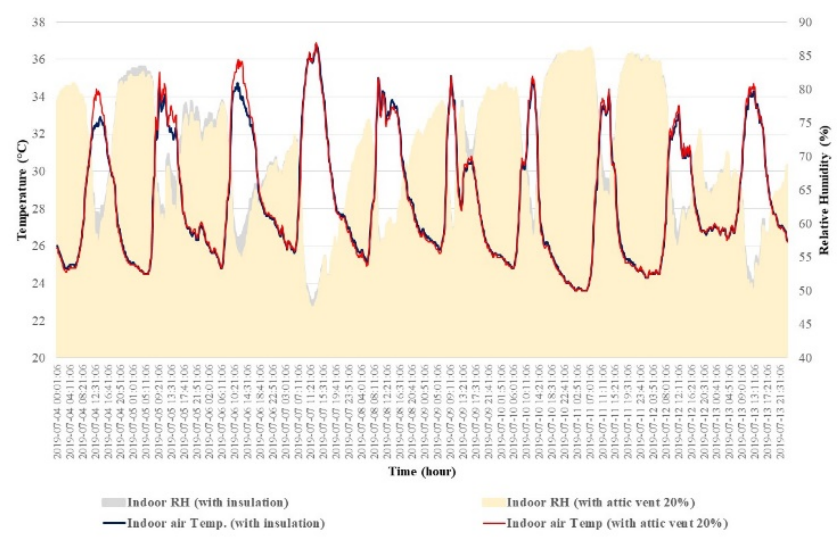

Fig. 5. Comparison of the indoor air temperature and air relative humidity from the ventilated roofs model and the model of the insulated roof 
Figure 6 shows in detail the conditions of indoor air temperature on a roof-ventilated model and a model with roof insulation. Indoor air temperature on the roof-ventilated model averages was lower than the air temperature in a roof insulated model of $0.1^{\circ} \mathrm{C}$. However, from 11 a.m. to 1 p.m., the indoor air temperature on the model with roof insulation is slightly below the air temperature of the roof ventilated model room.

This shows that the use of roof insulation has an effect on the indoor air temperature but it is difficult to conclude that its use significantly reduces room air temperature compared to the use of roof ventilation. Changes in the number of window openings that allow cross ventilation to be single-sided ventilation greatly affect the condition of indoor air temperature. This means that to reduce the indoor air temperature needs to pay attention to other parameters such as the ventilation strategy of the room.

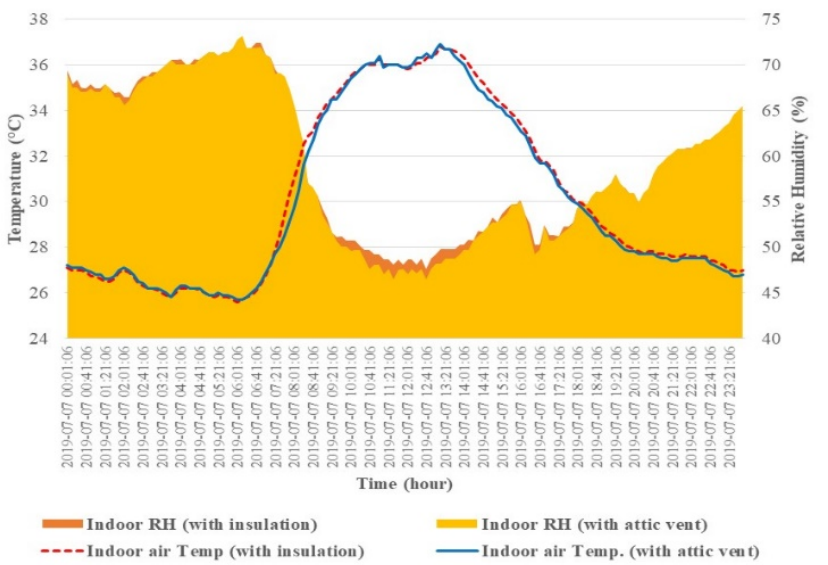

Fig. 6. Differences in detail in indoor air temperature from models that have roof ventilation and with roof with insulation

This discrepancy is evidenced by the results of measurements of air temperature in the attic between two models. The measurement results show that the attic air temperature in the roof ventilated model is always lower than the air temperature in the attic on roof insulated models, as shown in Fig.7.

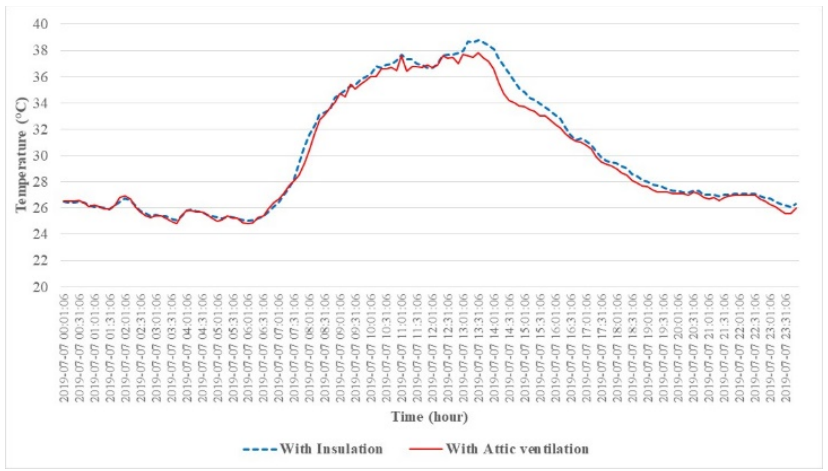

Fig. 7. Comparison of air temperature in attics of two test cells: the ventilated roof and the non-ventilated roof but installed insulation

The difference in attic air temperature between the two models ranges from -0.3 to $2.1^{\circ} \mathrm{C}$ or an average of $0.3{ }^{\circ} \mathrm{C}$, as shown in the following Fig. 8 . The biggest difference occurs at 12 a.m. to 3 p.m., while at 1 to 2 a.m. and 6 to 7 a.m., the attic air temperature of the model with an insulated roof is slightly higher than that of the roof-ventilated model.

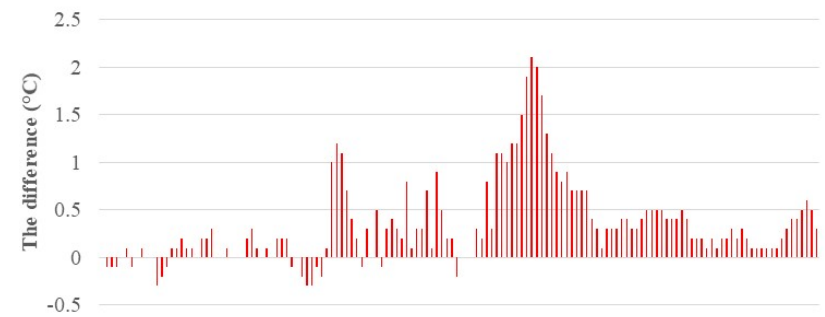

Fig. 8. Air temperature differences in attics for the roof-ventilated model and the model with insulated roofs

\section{CONCLUSIONS}

The use of attic ventilation is a wise consideration in adapting to the humid tropical climate; especially to avoid trapping hot air in the attic. By comparing the measurement results of the model having the attic ventilation of $20 \%$ as the Net Free Ventilation Area and the other model without attic ventilation, it is showed that the indoor air temperature of the ventilated roof is always lower than the unventilated roof, on average $1.2^{\circ} \mathrm{C}$.

Comparing with the model insulated roof produced different patterns in the profile of indoor air temperature. The difference is not too large, which is an average of $0.1^{\circ} \mathrm{C}$ lower for the roof-ventilated model. But from 11 a.m. to 1 p.m., the indoor air temperature on the roof with roof insulation is slightly below the air temperature of the roof ventilated model room. This is in accordance with the results of measurements of air temperature in the attic of the two models, the attic air temperature of the model having the attic ventilation is slightly lower than the roof insulated model in the average of $0.3^{\circ} \mathrm{C}$.

This study has shown that such as the use of attic ventilation, the use of roof insulation also affects decreasing attic air temperature; in turn, it will contribute to a decrease in the temperature of the indoor air. Further studies are needed especially to determine the effect of the area of roof ventilation openings on decreasing the indoor air temperature. The use of these two strategies provides benefits for achieving thermal comfort in humid tropical climates, especially in buildings with zinc roofs.

\section{ACKNOWLEDGMENT}

This research is part of the Penelitian Dasar Unggulan Perguruan Tinggi (PDUPT) in 2019-2020. We would like to thank the Ministry of Research, Technology, and Higher Education for funding this research.

\section{REFERENCES}

[1] D. Beal and S. Chandra, "The Measured Summer Performance of Tile Roof Systems and Attic Ventilation Strategies in Hot, Humid Climates". Thermal Envelopes VI/ Effects of Air MovementPrinciples, 1995

[2] W.B. Rose, "Control of moisture in the modern building envelope: the history of the vapor barrier in the United States 1923-1952". APT Bulletin, Vol. XVIII. No. 4, 1997

[3] U.S. Department of Housing and Urban Development, Manufactured Housing Research Alliance, "Attic Ventilation Design Strategies for Manufactured Homes”, 21 October 2002, New York, NY 10023

[4] Badan Pusat Statistik Provinsi Sulawesi Utara, "Sulawesi Dalam Angka 2015", Manado, 2016

[5] B. Givoni, “L'Homme, l'Architecture et le Climat", Paris: Editions du Moniteur, 1978, p. 460

[6] G. Lippsmeier, "Tropenbau, building in the tropics". Trad. By Nasution S. In Bangunan tropis, Jakarta: Penerbit Erlangga, 1994, p. 201 
[14] M. Ismail and A.M.A. Rahman, "Rooftop Turbine Ventilator: A Review and Update", Journal of Sustainable Development, Vol. 5, No. 5,2012

[8] J.I. Kindangen, "Pendinginan Pasif untuk Arsitektur Tropis Lembab", Deepublish, Yogyakarta, 2017, p. 241

[9] A. Ardiyanto, A. Djunaedi, Ikaputra, and J.A. Suryabrata, "The Architecture of Dutch Colonial Office in Indonesia and the Adaptation to Tropical Climate", International Journal of Scientific and Research Publications, Volume 5, Issue 4, April 2015, pp. 1-7

[10] Y. Sumalyo, "Dutch Colonial Architecture and City Development of Makassar", Dimensi Teknik Arsitektur, Vol. 30, No. 1, Juli 2002, pp. $46-53$.

[11] J.I. Kindangen and M.K. Umboh, "Design of Evaporative-Cooling Roof for Decreasing Air Temperature in Buildings in the Humid Tropics", in AIP Conference Proceedings 1818, 020023, 2017, pp. 020023-1- 020023-6, DOI: http://dx.doi.org/10.1063/1.4976887

[12] J.I. Kindangen, L. Tondobala, and M.K. Umboh, "Experimental Analysis of Cooling Performance of Spraying Water Automatically on the Galvanized Zinc-Roofs", International Journal of Engineering and Technology, Vol.10, No.2, 2018, pp. 414-422, DOI: 10.21817/ijet/2018/v10i2/181002014

[13] J.I. Kindangen and M.K. Umboh, "Study of Performance of Heat Exchanger Using Water and Sand for Zinc Roof Cooling with Automatic Water Spraying", ARPN Journal of Engineering and Applied Sciences, Vol. 13, No. 22, November 2018, pp. 8788-8794

[15] U.S. Department of Energy's Building America Program Office of Energy Efficiency and Renewable Energy, "Measure Guideline: Guide to Attic Air Sealing", 2014

[16] S.L. Quarles and A. TenWolde, "Attic and Crawlspace Ventilation: Implications for Homes Located in the Urban-Wildland Interface", Conference of Woodframe Housing Durability and Disaster Issues, October 4-6, 2004, Aladdin Resort, Nevada, USA

[17] J.L. Purswell and B.D. Lott, "Heating Poultry Houses with an Attic Ventilation System", 2007 ASABE Annual International Meeting Sponsored by ASABE Minneapolis Convention Center Minneapolis, Minnesota 17 - 20 June 2007.

[18] S. Ahmed, S.A. Rahman, and A. Zain-Ahmed, "The Ventilation Performance of a Solar Powered Attic Fan in Malaysian Climate", Conference on Sustainable Building South East Asia, 11 - 13 April 2005

[19] https://www.roofseal.com.my/wp-content/uploads/Radiant-BarrierWoven-fixfas.pdf accessed 12/07/2019 